\title{
PERLINDUNGAN HUKUM BAGI KONSUMEN STUDI KESADARAN HUKUM PEREDARAN DAGING SAPI DI BOYOLALI
}

\author{
Wahyudi Setiyawan ${ }^{1}$, Absori $^{2}$, Kelik Wardiono ${ }^{3}$ \\ ${ }^{1-3}$ Universitas Muhammadiyah Surakarta, Indonesia
}

DOI: 10.23917/humaniora.v20i2.10747

Submit: 25 April 2020. Revisi: 7 Juli 2020. Diterima: 6 Agustus 2020

Available Online: 28 Agustus 2020. Periode Terbit: Agustus 2020

\begin{tabular}{ll}
\hline Kata Kunci & Abstrak \\
\hline protection, & The research aimed to describe the public legal awareness \\
consumer, & about meat distribution and legal protection for the beef \\
meat & consumers through law enforcement efforts at Boyolali \\
& District based on a qualitative non-doctrinal approach. \\
& Therefore, this focused more on primary data collected by \\
& interviews and observations and supported by secondary data \\
\hline Corresponding & collected by library research. The data then were processed \\
Author & for further qualitative analysis. Based on the results of the \\
\hline Wahyudi Setiyawan & study it was found that legal protection related to the \\
Universitas & distribution of healthy and safe meat did not run well as this \\
Muhammadiyah & was influenced by the community legal, namely the knowledge \\
Surakarta, & and understanding of law, although it had been supported by \\
Indonesia & good legal attitudes and behavioral factors. \\
Email: &
\end{tabular}

\section{PENDAHULUAN}

Indonesia terkenal sebagai negara yang memiliki sumber daya alam yang melimpah dan beranekaragam. Salah satu sumber daya alam tersebut yang memiliki nilai ekonomi tinggi adalah sapi potong. Data yang diperoleh oleh penulis dari badan Pusat Statistik Nasional, data populasi sapi potong menurut Provinsi tahun 2009-2017, pada tahun 2017 jumlah sapi potong di Indonesia sebanyak 16.599.247 sapi potong dengan dengan jumlah produksi daging pada tahun 2017 sebesar 531756.98 ton. Kekayaan Indonesia akan sapi tersebut oleh masayarakat dimanfaatkan dengan membuka rumah potong hewan (RPH) dengan berdasarkan data hasil updating DPP dan DNRT 2017, menunjukkan jumlah RPH dan TPH di Indonesia adalah 1.201 yang tersebar di 34 provinsi dan 45 persen RPH/TPH terdapat di Pulau Jawa yakni sebanyak 527 RPH/TPH.

Dengan banyaknya rumah tangga yang memiliki sapi tersebut ternyata banyak juga pelaku usaha yang menginginkan keuntungan yang lebih besar dengan melakukan pembelian sapi yang mengalami keracunan, gangguan metabolisme, diare, dan atau karena berbagai hal lainnya yang menyebabkan sapi tersebut mati atau sapi yang digelonggong yang perbuatan tersebut akan memberikan nilai keuntungan yang diperoleh oleh oknum akan semakin besar.

Pengaturan jaminan keamanan peredaran daging di dalam ajaran agama Islam hal ini diatur di dalam surat Al-Baqarah ayat 173, kemudian di dalam hukum positif Indonesia. Terkait dengan hal tersebut telah diatur di dalam UU No. 18 Tahun 2012 tentang Pangan, Undang-Undang No. 41 Tahun 2014 tentang Perubahan atas Undang-undang 
Nomor 18 tahun 2009 tentang Peternakan dan Kesehatan Hewan, Undang-Undang No. 36 Tahun 2009 tentang Kesehatan, Undang-Undang Nomor 8 tahun 1999 tentang Perlindungan Konsumen, Undang-Undang No. 33 Tahun 2014 tentang Jaminan Produk Halal, Peraturan Pemerintah Nomor 28 Tahun 2004 tentang Keamanan, Mutu, dan Gizi Pangan, Peraturan Kepala BPOM No.14 Tahun 2014 tentang Organisasi dan tata Kerja Unit Pelaksana Teknis di Lingkungan Badan Pengawas Obat dan Makanan

Walaupun ada beberapa peraturan yang telah mengatur terkait dengan keamanan daging sapi, akan tetapi pada kenyataanya masih banyak oknum yang menjual daging yang tidak aman dan sehat seperti dalam Putusan Nomor 187/Pid.Sus/2018/PN Mgt (Peternakan dan Kesehatan Hewan) dimana pelaku telah terbukti secara sah dan meyakinkan bersalah melakukan tindak pidana menyelenggarakan kegiatan pengangkutan dan peredaran pangan yang tidak memenuhi persyaratan sanitasi pangan yaitu mengangkut sebanyak $300 \mathrm{~kg}$ daging yang merupakan daging sapi gelonggongan dengan ciri-ciri fisik daging terlihat basah dengan kandungan air berlebih.

Hal tersebut perlu diteliti sebab keamanan pangan bagi produsen dan konsumen sangat penting karena daging sapi yang tidak aman dan sehat dapat mengakibatkan bahaya dan atau timbulnya penyakit dan berbahaya (food-borne diseases). Oleh karena itu, diperlukan upaya penegak hukum yang tegas karena peredaran makanan yang baik dan aman berarti turut serta meningkatkan terwujudnya kesejahteraan negara. Sementara itu, pengaturan di dalam peraturan-peraturan yang ada belum memberikan pengaturan yang jelas baik terkait dengan penegakan hukum yang harus dilakukan ataupun penggolongan daging aman dan sehat tersebut, yang pada akhirnya menyebabkan penegakan hukum belum memadai atau sesuai dengan ekspetasi yang akhirnya berdampak kepada perlindungan konsumen untuk memperoleh daging yang sehat.

Berdasarkan deskripsi tentang problematika penelitian di atas, maka masalahnya dirumuskan: (1) Bagaimana perlindungan hukum terhadap perearan daging sapi di Kabupaten Boyolali, (2) Bagaimana konsep perlindungan hukum terhadap peredaran daging sapi berbasis kesadaran hukum masyarakat? . Tujuan dalam penelitian ini adalah untuk mendeskripsikan dan mengeksplanasi perlindungan hukum terhadap peredaran daging sapi di Kabupaten Boyolali dan konsep perlindungan hukum terhadap peredaran daging sapi berbasis kesadaran hukum masyarakat.

\section{METODE}

Penelitian ini mendasarkan metode pendekatan non-doktrinal kualitatif. Lokasi penelitian dilakukan di wilayah Kabupaten Boyolali. Jenis data yang digunakan dalam penelitian ini adalah data primer yang diperoleh dari wawancara dan penyebaran quisioner, wawancara dilakukan kepada masyarakat Boyolali dan Dinas Pertenakan Boyolali, Dinas Kesehatan Boyolali dan Kepolisian Reserse Boyolali, penyebaran quisioner dengan mengambil sampel di Boyolali sebanyak 266 responden yang setiap responden mewakili kelurahan yang ada di masing masing kecamatan yang berjumlah 19 kecamatan dan 266 desa, teknik pengumpulan data yang dipergunakan adalah dengan penyebaran quisoner dengan media cetak dan kuesioner melalui google form. Dasar penentuan responden ini dipilih oleh penulis secara acak dan diprioritaskan bekerja sebagai petani, dengan demikian penulis dalam melakukan penyebaran quisioner dilakukan ke daerah persawahan atau perkebunan yang tersebar di Kabupaten Boyolali dengan landasan mayoritas petani pernah memelihara sapi atau setidaknya pernah mengkonsumsi daging sapi, dan data sekunder yang diperoleh dari studi kepustakaan yaitu peraturan Menteri Pertanian Republik Indonesia Nomor 13/Permentan/OT.140/1/2010 tentang persyaratan rumah potong hewan ruminansia dan unit penanganan daging (Meat Cutting Plant).

Metode analisis data yang digunakan yaitu analisis domain, analisis taksonomis, analisis komponensial, dan penafsiran data. Untuk membahas hasil penelitian ini penulis menggunakan teori kesadaran hukum. Kesadaran hukum yang diteliti disini adalah kesadaran hukum masyarakat terhadap peredaran daging sapi di Kabupaten Boyolali,. 


\section{HASIL}

Perwujudan hak atas kesehatan bisa dicapai dengan beberapa pendekatan yang beragam contohya pembentukan kebijakan-kebijakan kesehatan atau pelaksaan programprogram yang dibentuk oleh World Health Organization (WHO) atau adopsi instrument hukum. Penulis merujuk peraturan Menteri Pertanian Republik Indonesia Nomor 13/Permentan/OT.140/1/2010 tentang Persyaratan Rumah Potong Hewan Ruminansia dan unit Penanganan Daging (Meat Cutting Plant) yang akan menjadi tolak ukur penelitian dalam menjawab perlindungan hukum terhadap peredaran daging sapi di Kabupaten Boyolali. Dalam upaya memperoleh data dilakukan observasi dan wawancara terhadap 10 pengusaha sapi di Kabupaten Boyolali yang hasil penelitiannya yaitu sebagai berikut:

\begin{tabular}{|c|c|c|c|c|c|c|c|c|c|c|c|c|c|c|c|c|c|c|c|c|c|c|}
\hline \multirow{2}{*}{$\begin{array}{c}\text { NAMA } \\
\text { PELAK } \\
\text { U } \\
\text { USAHA }\end{array}$} & \multirow{2}{*}{ ALAMAT } & \multicolumn{5}{|c|}{ A } & \multicolumn{3}{|c|}{ B } & \multicolumn{6}{|c|}{$\mathrm{C}$} & \multicolumn{5}{|c|}{$\mathrm{D}$} & \multirow{2}{*}{$\mathrm{E}$} & \multirow{2}{*}{$\mathrm{F}$} \\
\hline & & 1 & 2 & 3 & 4 & 1 & 2 & 3 & 4 & 1 & 2 & 3 & 4 & 5 & 6 & 1 & 2 & 3 & 4 & 5 & & \\
\hline BARI & Seboto, Ampel & $\sqrt{ }$ & $\mathrm{X}$ & $\mathrm{X}$ & $\mathrm{X}$ & $\sqrt{ }$ & $\mathrm{X}$ & $\mathrm{X}$ & $\mathrm{X}$ & $\mathrm{X}$ & $\sqrt{ }$ & $\sqrt{ }$ & $\mathrm{X}$ & $\mathrm{X}$ & $\sqrt{ }$ & $\mathrm{X}$ & $\mathrm{X}$ & $\mathrm{X}$ & $\mathrm{X}$ & $\mathrm{X}$ & $\sqrt{ }$ & $\mathrm{X}$ \\
\hline Ndakir & $\begin{array}{l}\text { Bakalan, Am- } \\
\text { pel }\end{array}$ & $\sqrt{ }$ & $\sqrt{ }$ & $\sqrt{ }$ & $\sqrt{ }$ & $\sqrt{ }$ & $\sqrt{ }$ & $\mathrm{X}$ & $\mathrm{X}$ & $\sqrt{ }$ & $\sqrt{ }$ & $\sqrt{ }$ & $\sqrt{ }$ & $\sqrt{ }$ & $\sqrt{ }$ & $\sqrt{ }$ & $\sqrt{ }$ & $\mathrm{X}$ & $\sqrt{ }$ & $\sqrt{ }$ & $\sqrt{ }$ & $\mathrm{X}$ \\
\hline Sarono & Meseng, Ampel & $\sqrt{ }$ & $\mathrm{X}$ & $\mathrm{X}$ & $\sqrt{ }$ & $\mathrm{X}$ & $\mathrm{X}$ & $\mathrm{X}$ & $\mathrm{X}$ & $\mathrm{X}$ & $\sqrt{ }$ & $\sqrt{ }$ & $\mathrm{X}$ & $\mathrm{X}$ & $\sqrt{ }$ & $\mathrm{X}$ & $\mathrm{X}$ & $\mathrm{X}$ & $\mathrm{X}$ & $\mathrm{X}$ & $\sqrt{ }$ & $\mathrm{X}$ \\
\hline WIranto & Seboto, Ampel & $\sqrt{ }$ & $\sqrt{ }$ & $\mathrm{X}$ & $\sqrt{ }$ & $\sqrt{ }$ & $\sqrt{ }$ & $\mathrm{X}$ & $\mathrm{X}$ & $\sqrt{ }$ & $\sqrt{ }$ & $\sqrt{ }$ & $\mathrm{X}$ & $\mathrm{X}$ & $\sqrt{ }$ & $\mathrm{X}$ & $\mathrm{X}$ & $\mathrm{X}$ & $\mathrm{X}$ & $\mathrm{X}$ & $\sqrt{ }$ & $\mathrm{X}$ \\
\hline Widadi & $\begin{array}{l}\text { Sunggingan, } \\
\text { Boyolali }\end{array}$ & $\mathrm{X}$ & $\mathrm{X}$ & $\mathrm{X}$ & $\sqrt{ }$ & $\mathrm{X}$ & $\mathrm{X}$ & $\mathrm{X}$ & $X$ & $\sqrt{ }$ & $\sqrt{ }$ & $\sqrt{ }$ & $\mathrm{X}$ & $\mathrm{X}$ & $\mathrm{X}$ & $\sqrt{ }$ & $\sqrt{ }$ & $\mathrm{X}$ & $\sqrt{ }$ & $\sqrt{ }$ & $\sqrt{ }$ & $\mathrm{X}$ \\
\hline Agung & $\begin{array}{l}\text { Daleman, } \\
\text { Cepogo }\end{array}$ & $\mathrm{X}$ & $\mathrm{X}$ & $\mathrm{X}$ & $\sqrt{ }$ & $\mathrm{X}$ & $\mathrm{X}$ & $\mathrm{X}$ & $\mathrm{X}$ & $\mathrm{X}$ & $\sqrt{ }$ & $\sqrt{ }$ & $\mathrm{X}$ & $\mathrm{X}$ & $\mathrm{X}$ & $\mathrm{X}$ & $\sqrt{ }$ & $\mathrm{X}$ & $\sqrt{ }$ & $\mathrm{X}$ & $\mathrm{X}$ & $\mathrm{X}$ \\
\hline Joko & $\begin{array}{l}\text { Kenteng, Am- } \\
\text { pel }\end{array}$ & $\mathrm{X}$ & $\mathrm{X}$ & $\mathrm{X}$ & $\sqrt{ }$ & $\mathrm{X}$ & $\mathrm{X}$ & $\mathrm{X}$ & $\mathrm{X}$ & $\sqrt{ }$ & $\sqrt{ }$ & $\sqrt{ }$ & $\sqrt{ }$ & $\sqrt{ }$ & $\mathrm{X}$ & $\mathrm{X}$ & $\mathrm{X}$ & $\mathrm{X}$ & $\mathrm{X}$ & $\mathrm{X}$ & $\mathrm{X}$ & $\mathrm{X}$ \\
\hline Ari & Gubug, Ampel & $\mathrm{X}$ & $\mathrm{X}$ & $\mathrm{X}$ & $\mathrm{X}$ & $\mathrm{X}$ & $\mathrm{X}$ & $\mathrm{X}$ & $\mathrm{X}$ & $\mathrm{X}$ & $\sqrt{ }$ & $\sqrt{ }$ & $\mathrm{X}$ & $\mathrm{X}$ & $\mathrm{X}$ & $\mathrm{X}$ & $\mathrm{X}$ & $\mathrm{X}$ & $\mathrm{X}$ & $\mathrm{X}$ & $\mathrm{X}$ & $\mathrm{X}$ \\
\hline Bingan & $\begin{array}{l}\text { Gubung, Am- } \\
\text { pel }\end{array}$ & $\mathrm{X}$ & $\mathrm{X}$ & $\mathrm{X}$ & $\mathrm{X}$ & $\mathrm{X}$ & $\mathrm{X}$ & $\mathrm{X}$ & $\mathrm{X}$ & $\mathrm{X}$ & $\sqrt{ }$ & $\sqrt{ }$ & $\mathrm{X}$ & $\mathrm{X}$ & $\mathrm{X}$ & $\mathrm{X}$ & $\mathrm{X}$ & $\mathrm{X}$ & $\mathrm{X}$ & $\mathrm{X}$ & $\mathrm{X}$ & $\mathrm{X}$ \\
\hline Ahmadi & $\begin{array}{l}\text { Semalang, Bo- } \\
\text { yolali }\end{array}$ & $\sqrt{ }$ & $\sqrt{ }$ & $X$ & $\sqrt{ }$ & $\sqrt{ }$ & $\sqrt{ }$ & $X$ & $\mathrm{X}$ & $\sqrt{ }$ & $\sqrt{ }$ & $\sqrt{ }$ & $\sqrt{ }$ & $\sqrt{ }$ & $\sqrt{ }$ & $\sqrt{ }$ & $\sqrt{ }$ & $X$ & $\sqrt{ }$ & $\sqrt{ }$ & $\sqrt{ }$ & $X$ \\
\hline
\end{tabular}

\section{Keterangan:}

$\begin{array}{ll}\sqrt{ } & : \text { Sesuai dengan Ketentuan Perundang-undangan } \\ X & : \text { Tidak Sesuai dengan Ketentuan Perundang-undangan }\end{array}$

Ketentuan Peredaran Daging Sapi

1. Persyaratan Rumah Potong Hewan

a. Lokasi (Pasal 6)

b. Persyaratan sarana pendukung (Pasal 7)

c. Persyaratan tata letak, desain dan kontruksi (Pasal 8)

d. Persyaratan peralatan (Pasal 29)

2. Persyaratan Unit Penaganan Daging (Meat Cutting Plant) (Pasal 30)
a. Lokasi (Pasal 31)
b. Persyaratan sarana pendukung (Pasal 32)
c. Persyaratan tata letak, desain dan kontruksi dasar (Pasal 33)
d. Persyaratan peralatan (Pasal 34) 
3. Persyaratan Higiene dan Sanitasi (Pasal 35)

a. Peralatan mencuci sepatu boot (Pasal 35 ayat 3)

b. Fasilitas cuci tangan (Pasal 35 ayat 4)

c. Fasilitas mencuci pisau (Pasal 35 ayat 6)

d. Tidak menggunakan bahan kima berbahaya (Pasal 35 ayat 7)

e. Dilakuakn proses pembersihan dan desinfeksi pemotongan daging (Pasal 35 ayat 8)

f. Kebersihan lingkungan (Pasal 35 ayat 9)

4. Pengawasan Kesehatan Masyarakat Veteriner (Pasl 37)

a. Penerapan kesehatan hewan di RPH (Pasal 37 ayat 2 huruf a)

b. Pemeriksaan kesehatan hewan sebelum disembelih (ante-motem inspection) (Pasal 37 ayat 2 huruf b)

c. Pemeriksaan kesempuraan proses pemingsanan (Stunning) (Pasal 37 ayat 2 huruf c)

d. Pemeriksaan kesehatan jeroan dan/atau karkas (Post-mortem inspection) (Pasal 37 ayat 2 huruf d)

e. Pemeriksaan pemenuhan persyaratan hygiene-sanitasi pada proses Produksi (Pasal 37 ayat 2 huruf e).

5. Izin mendirikan rumah potong hewan dan izin usaha pemotongan hewan (Pasal 38)

6. Sumber daya manusia (Pasal 41)

Dari tabel di atas diperoleh penjelasan yaitu sebagai berikut:

\section{Persyaratan Rumah Potong Hewan}

Dari data yang diperoleh oleh penulis menunjukkan bahwa hanya satu pelaku usaha di Boyolali yang memenuhi persyaratan tersebut yaitu Ndakir, selain itu pelaku usaha lain ada yang sepenuhnya tidak sesuai dan ada yang beberapa yang tidak sesuai dan sudah ada yang sesuai. Meskipun tidak sesuai operasional, rumah potong hewan ini tetap berjalan dengan rutinitas seperti biasanya padahal seperti misalnya peralatan yang tidak mendukung atau korosif akan menyebabkan mutu daging tidak sehat dan aman karena terkontaminasi dengan peralatan yang tidak sehat tersebut

\section{Persyaratan Unit Pelayanan Daging}

Dari hasil penelitian yang dilakukan penulis hasilnya dari beberapa ketentuan mengenai persyaratan tata letak, desain dan kontruksi yang mendukung, tidak ada pelaku usaha di Kabupaten Boyolali yang sesuai dengan ketentuan yang telah ditentukan oleh peraturan.

\section{Persyaratan Higiene dan Sanitasi}

Dari data yang diperoleh hanya pelaku usaha Ndakir dan Ahmadi yang telah sesuai dengan ketentuan tersebut, hal ini menunjukan apabila mayoritas pelaku usaha lain tidak memperhatikan persyaratan higiene dan sanitasi, padahal sebagaimana yang telah diuriakan sebelumnya ketentuan ini akan mempengaruhi kesehatan konsumen karena daging yang dihasilkan tersebut.

\section{Pengawasan Kesehatan Masyarakat Veteriner}

Dari data yang diperoleh pada kenyataanya tidak ada satu pun pelaku usaha yang dilakukan observasi memenuhi ketentuan tersebut.

5. Izin Mendirikan Rumah Potong Hewan dan Izin Usaha Pemotongan Hewan

Dari data yang diperoleh penulis penulis dari 10 pelaku usaha di Kabupaten Boyolali hasilnya 6 pelaku usaha memiliki izin semantara 4 lainnya tidak memiliki izin usaha. 


\section{Sumber Daya Manusia}

Data yang diperoleh penulis hasilnya tidak ada satupun pelaku usaha yang memenuhi ketentuan ini, seluruhnya hanya memiliki tenaga ahli di dalam pemotongan hewan akan tetapi untuk dokter hewan tidak dimiliki.

Hasil kuesioner yang disebarkan kepada responden terkait dengan kesadaran hukum masyarakat terhadap peredaran daging sapi di Kabupaten Boyolali yaitu dengan memperhatikan beberapa aspek teori kesadaran hukum yaitu meliputi:

\section{Pengetahuan Hukum}

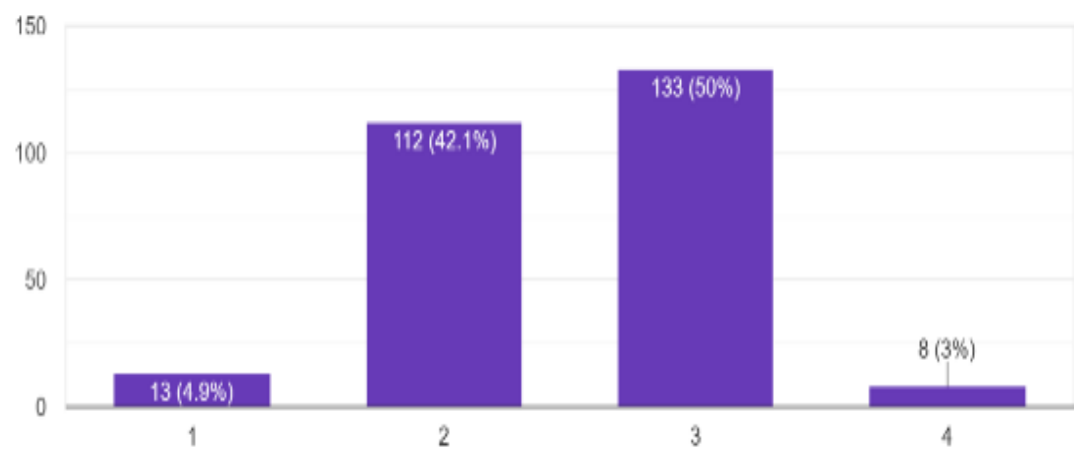

Gambar 1. Grafik Penjualan Sapi Diatur oleh Hukum

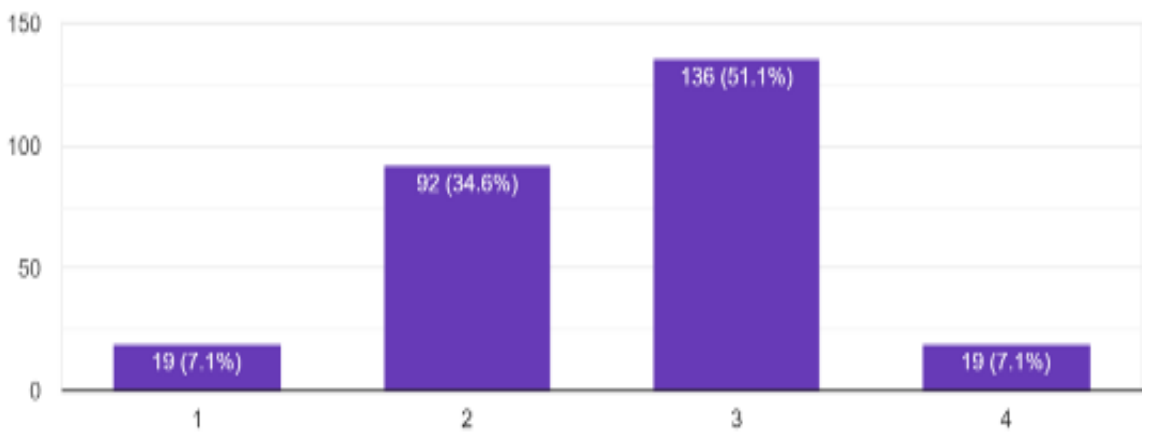

Gambar 2. Grafik Penjualan Daging Sapi Diatur di dalam Peraturan Perlindungan

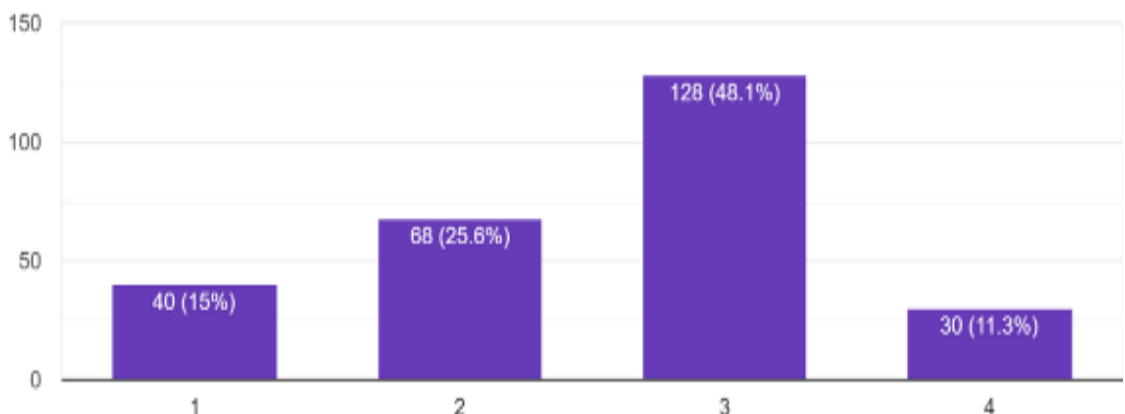

Gambar 3. Grafik Penegakan Hukum terhadap Daging Sapi yang Sehat dan Aman

Dari data yang diperoleh oleh penulis kepada 266 Responden dengan mengajukan pertanyaan mengenai pengetahuan hukum hasilnya lebih dari $50 \%$ masyarakat setuju atau sangat setuju, sementara itu di bawah $50 \%$ masyarakat tidak setuju, hal ini menunjukan apabila pengetahuan masyarakat hukum tergolong baik, akan tetapi hal ini juga menjadi 
kekurangan karena setuju tidak lebih dari $60 \%$ rata-rata. Dengan demikian, masih ada sebanyak $40 \%$ masyarakat di Kabupaten Boyolali yang tidak memiliki pengetahuan hukum mengenai peredaran daging sapi Kabupaten Boyolali. Oleh karena itu, dari $40 \%$ masyarakat yang tidak setuju menunjukkan korelasi yang sesuai dengan bentuk perlindungan hukum yang tidak berjalan sesuai dengan ketentuan yang ada, hal ini dikarenakan pemahaman hukum masyarakat mengenai daging sehat dan aman oleh masyarakat masih sangat kurang dan minim.

\section{Pemahaman Hukum}

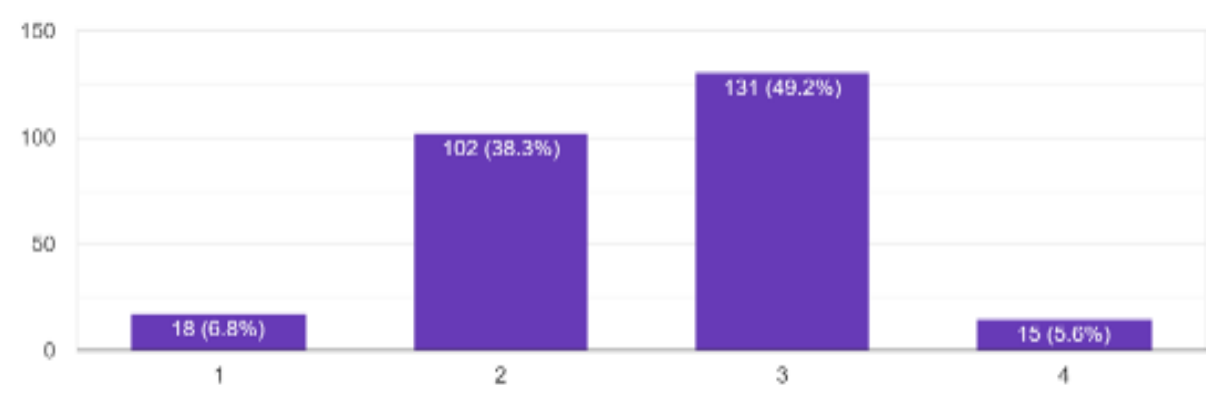

Gambar 4. Grafik Penjualan dan Pembelian Sapi yang Tidak Aman dan Sehat

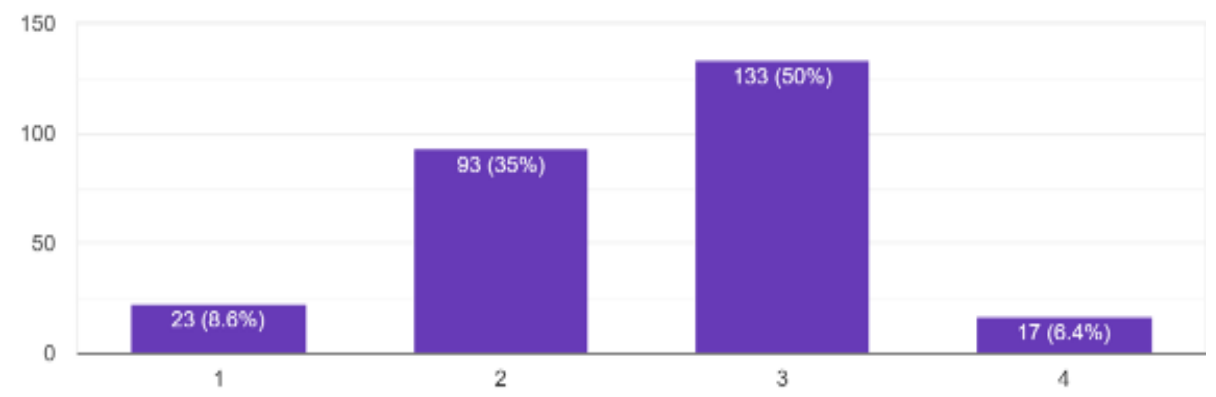

Gambar 5. Grafik Penjualan Daging Sapi yang Tidak Aman dan Tidak Sehat Dapat

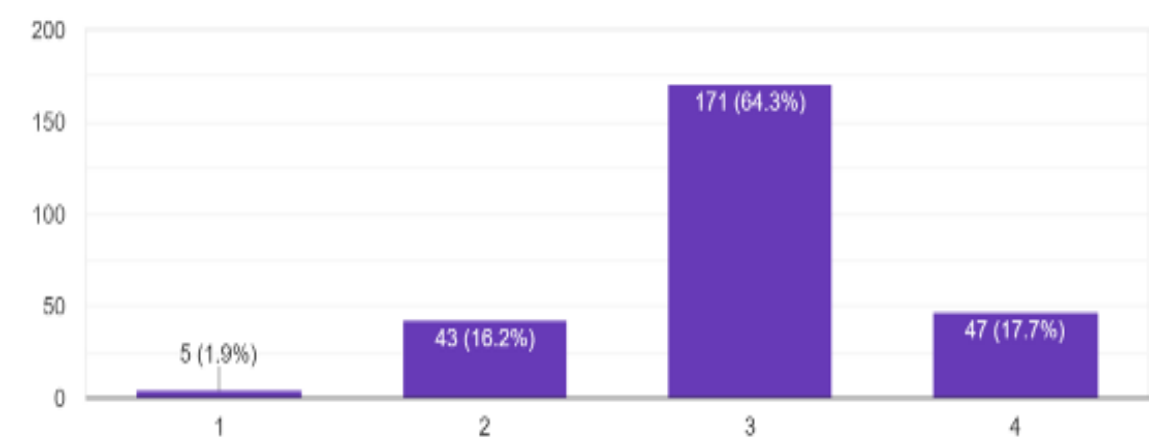

Gambar 6. Grafik Setiap Konsumen Mempunyai Hak untuk Memperoleh Daging Sapi yang Sehat dan Aman

Dalam hal ini data yang diperoleh dari 266 responden hasilnya pemahaman hukum lebih dari $60 \%$ rata-rata masyarakat setuju dengan demikian masih ada sebanyak $40 \%$ masyarakat di Kabupaten Boyolali tidak mengetahui pengetahuan hukum mengenai peredaran daging sapi di Kabupaten Boyolali. Pemahaman hukum ini sangat penting dikarenakan akan mempengaruhi pola perilaku masyarakat dalam melakukan pembelian daging sapi. Data yang disebutkan tersebut menunjukkan apabila pemahaman hukum 
masyarakat masih banyak yang tidak paham hal ini ditunjukkan dengan masih ada $40 \%$ masyarakat yang tidak paham mengenai hukum mengenai peredaran daging sapi. Hal ini akan mengakibatkan tingkat perlindungan hukum yang dilakukan oleh pemerintah rendah.

\section{Sikap Hukum}

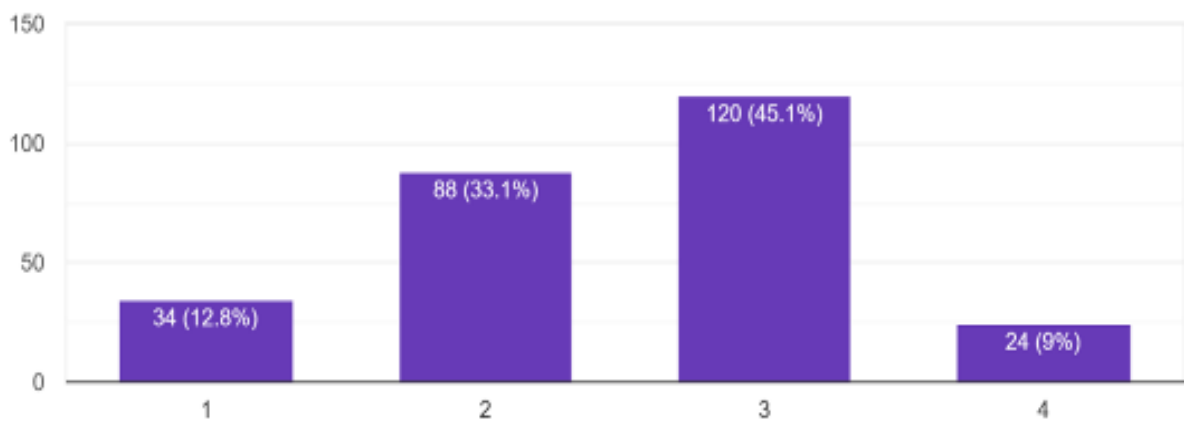

Gambar 7. Grafik Penjualan Sapi yang Tidak Aman dan Sehat Wajib Dikenai Sanksi

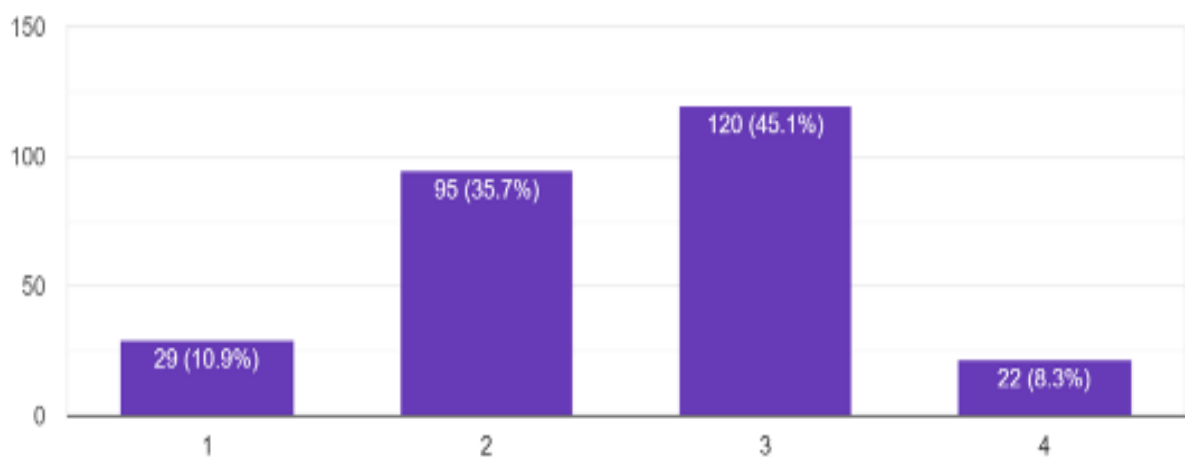

Gambar 8. Grafik Pembelian Sapi yang Melanggar Peraturan Perundang-Undangan Wajib Dikenai Sanksi

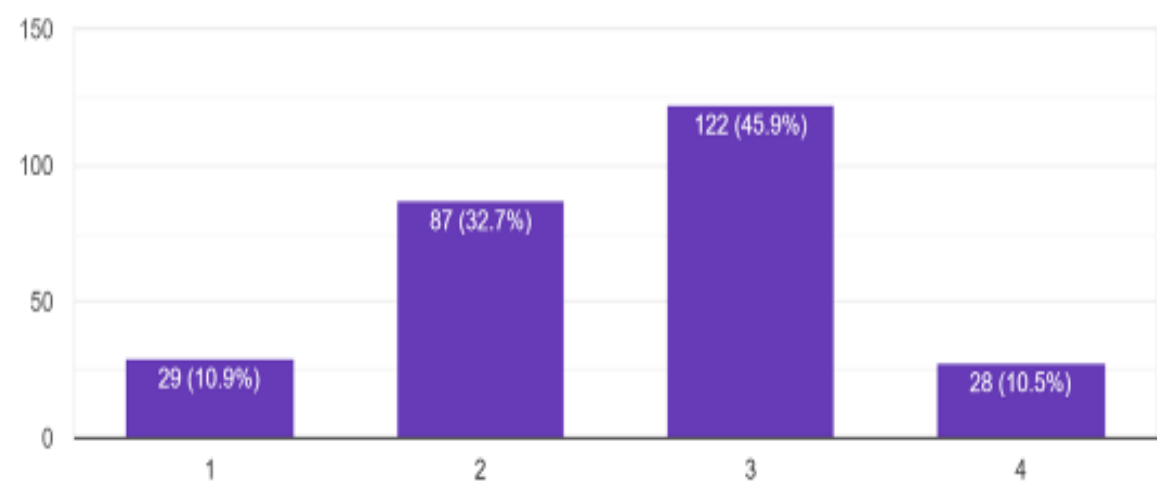

Gambar 9. Grafik Penjualan Daging Sapi yang Tidak Aman dan Tidak Sehat Wajib Dikenai Sanksi 
150

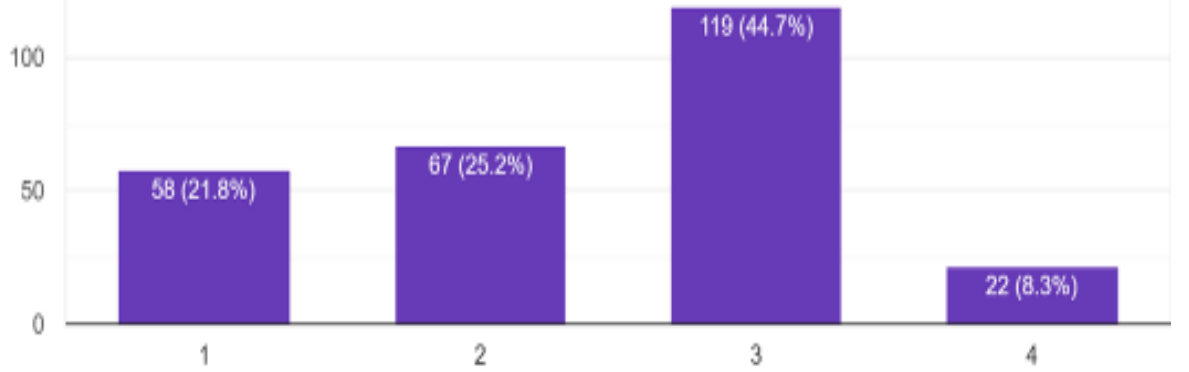

Gambar 10. Grafik Sanksi bagi Pelaku Penjualan Daging Sapi yang Tidak Sehat dan Aman Berupa Pidana

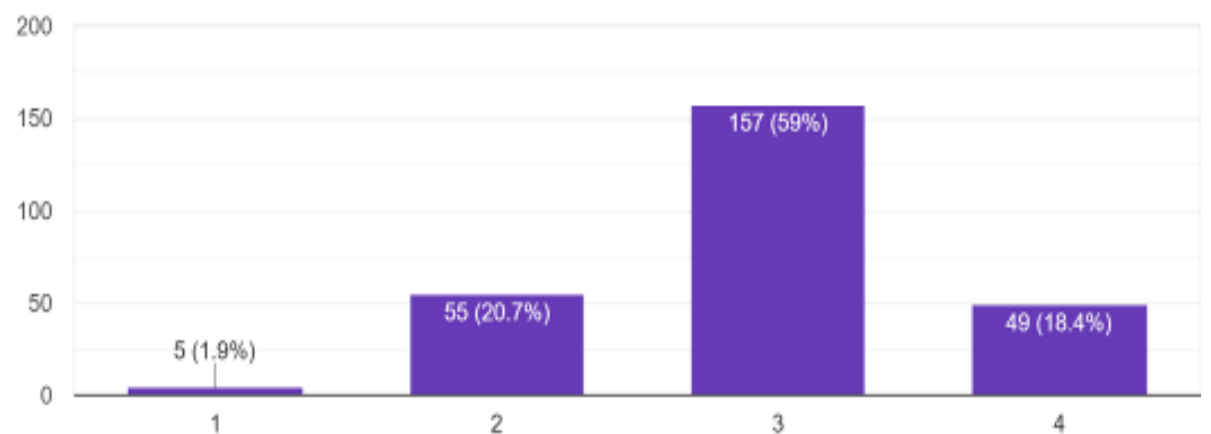

Gambar 11. Hak Konsumen untuk Memperoleh Dagng Sapi yang Sehat dan Aman Wajib Dilindungi

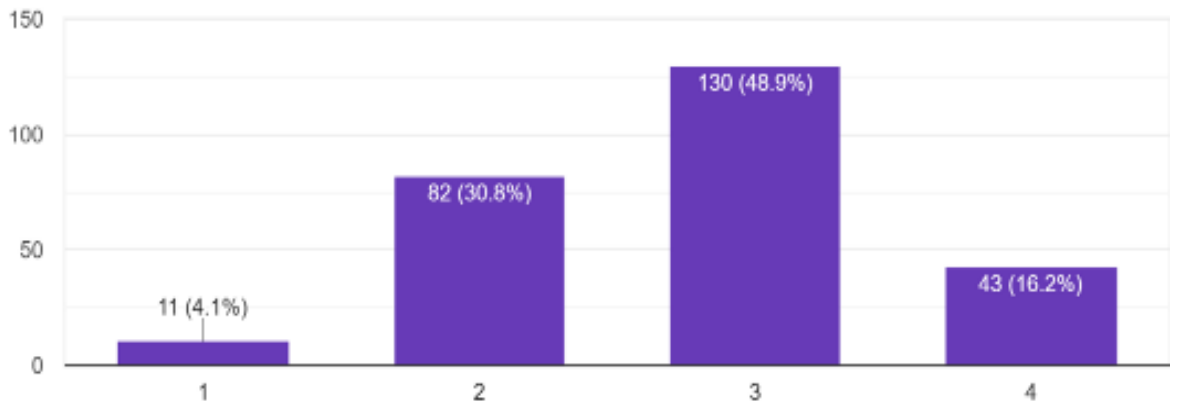

Gambar 12. Grafik Pembelian Daging Sapi yang Tidak Sehat dan Aman Merugikan Pihak Konsumen dan Merupakan Kegiatan Melanggar Hukum

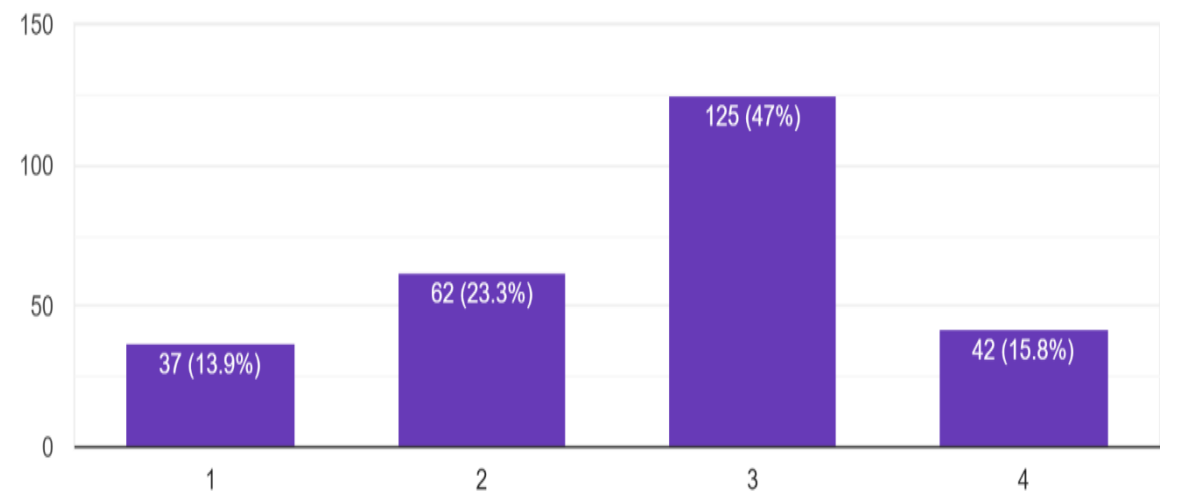

Gambar 13. Grafik Penegakan Hukum Harus Lebih Aktif dalam Menegakan Peredaran Daging Sapi yang Tidak Aman dan Sehat 
Hasilnya rata-rata 50-60\% masyarakat setuju atau sangat setuju, sementara 40-50\% masyarakat tidak setuju. Pertanyaan yang diajukan yaitu terkait dengan pengenaan sanksi bagi penjual sapi yang tidak aman dan sehat, pemberlian sapi yang melanggar peraturan perundang-undangan untuk wajib dikenai sanksi, penjualan daging yang tidak dan aman wajib dikenai sanksi, sanksi bagi pelaku penjual yaitu pidana, sementara pertanyaan mengenai hak konsumen untuk memperoleh daging sapi yang sehat dan aman wajib dilindungi, Pembelian daging sapi yang tidak sehat dan aman merugikan pihak konsumen dan merupakan kegiatan melanggar hukum, penegakan hukum harus lebih aktif dalam menegakan peredaran daging sapi yang tidak aman dan sehat hasilnya sangat mutlak masyarakat setuju sekitar $80 \%$ dan $20 \%$ tidak setuju.

\section{Pola Perilaku Hukum}

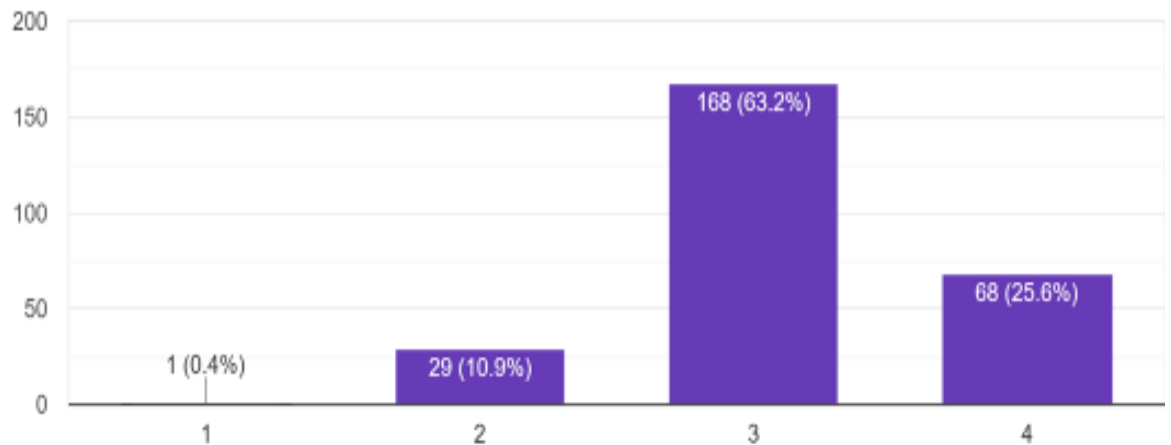

Gambar 14. Grafik Saya Menjaul Sapi yang Sehat dan Aman

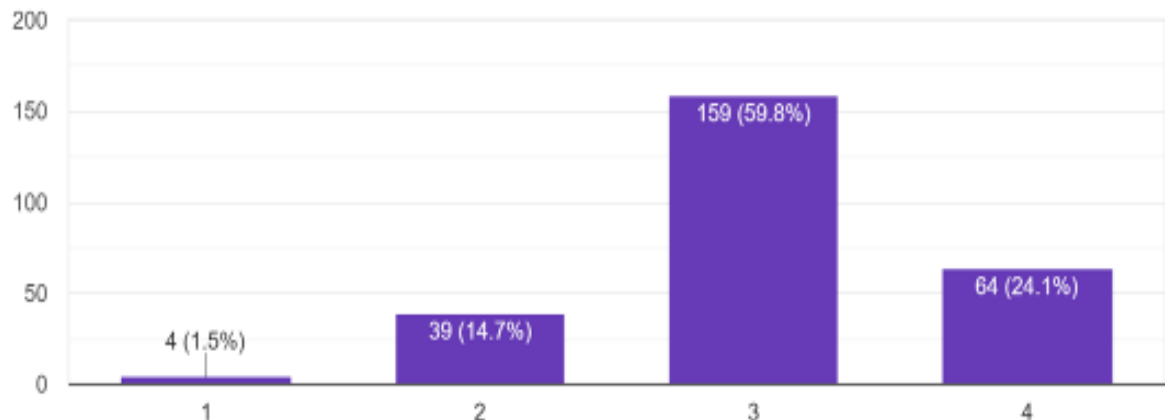

Gambar 15. Sebelum Menjual/Membeli Sapi Saya Memastikan Sapi yang Dijual Sehat dan Aman

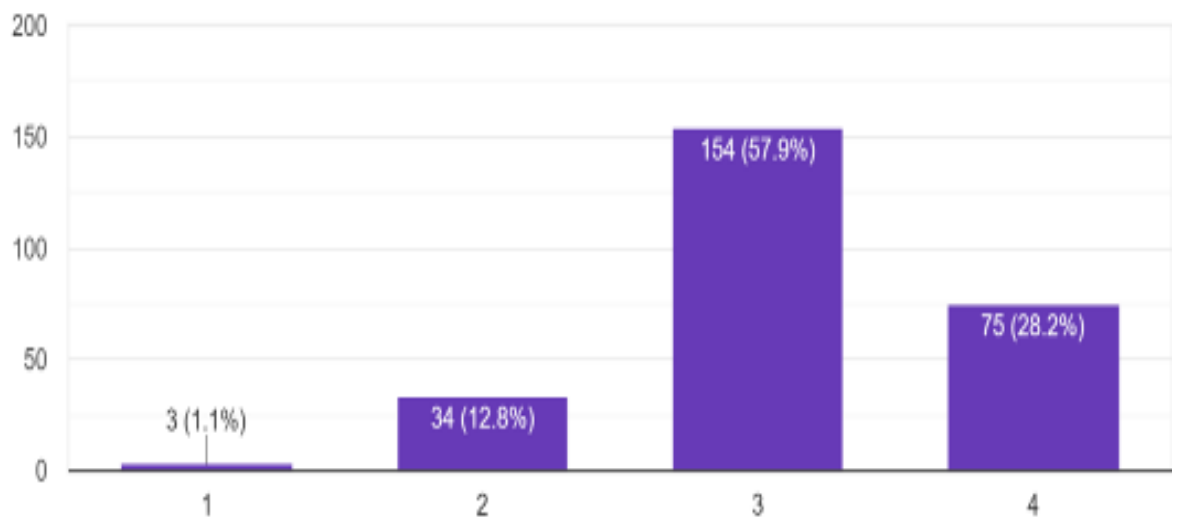

Gambar 16. Grafik dalam Membeli Daging Sapi Saya Mengecek Terlebih Dahulu Kualitasnya 
150

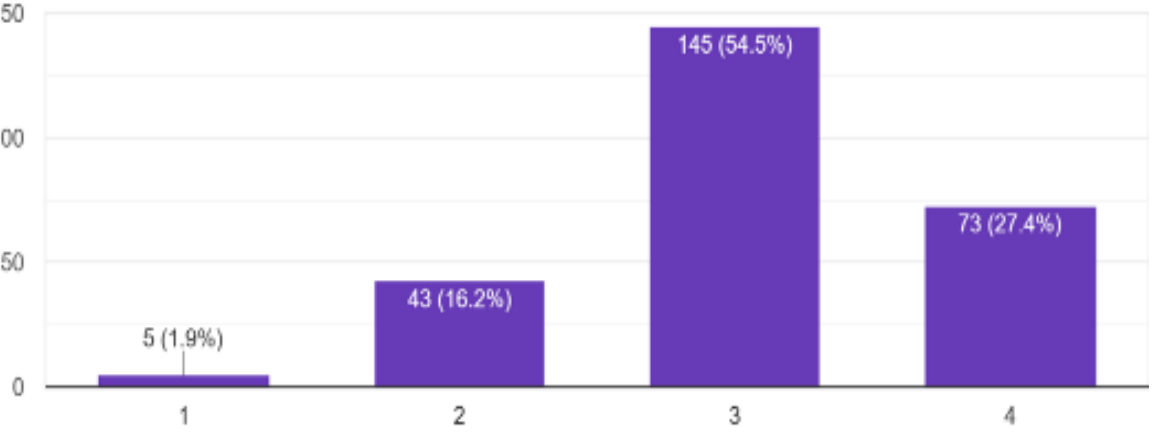

Gambar 17. Grafik Jika Sapi Saya Sakit Atau Meninggal Saya Tidak Akan Menjualnya ke Pemotongan Hewan

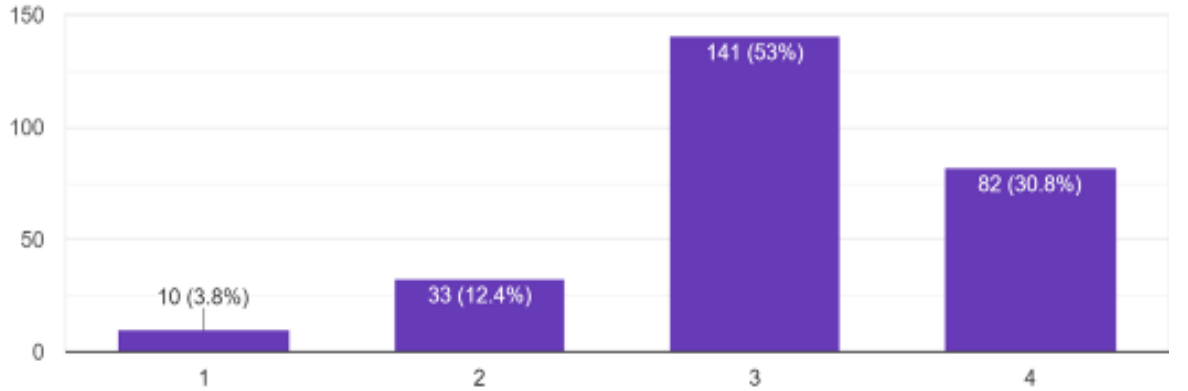

Gambar 18. Grafik Saya Tidak Akan Menjual Daging Sapi yang Tidak Aman dan Sehat bagi Konsumen

150

100

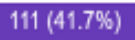

50

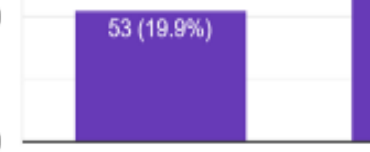

Gambar 19. Grafik Jika Saya Mengetahui Perilaku Masyarakat yang Melakukan Penjualan Sapi/Daging Sapi yang Tidak Aman dan Sehat Saya Melaporkan ke Aparat Penegak Hukum

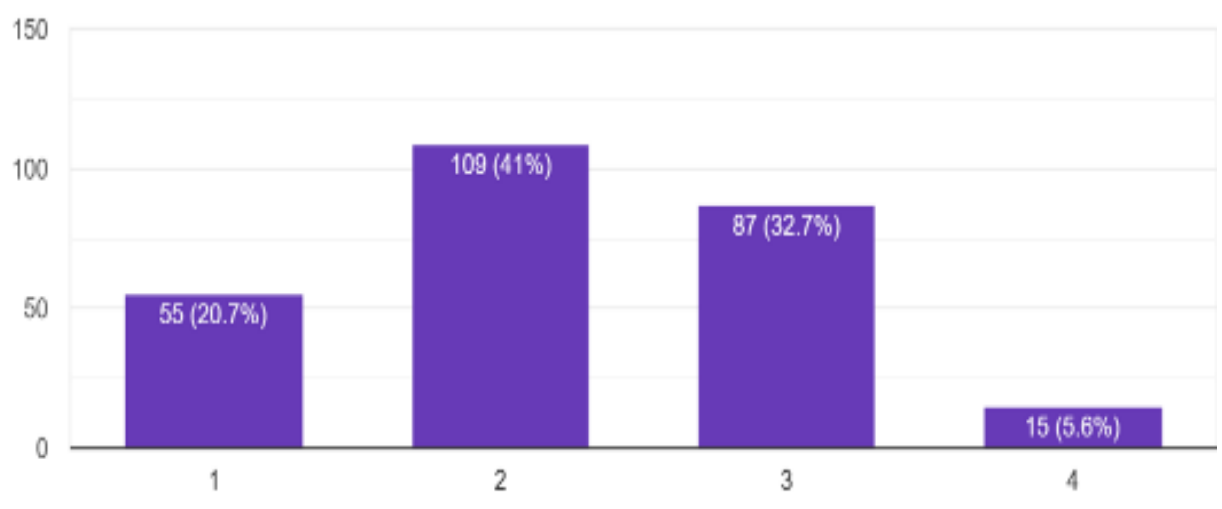

Gambar 20. Grafik Jika Saya Mengetahui Perilaku Penjual yang Melakukan Penjualan Sapi yang Tidak Aman dan Sehat Saya Melaporkan ke Aparat Penegak Hukum 


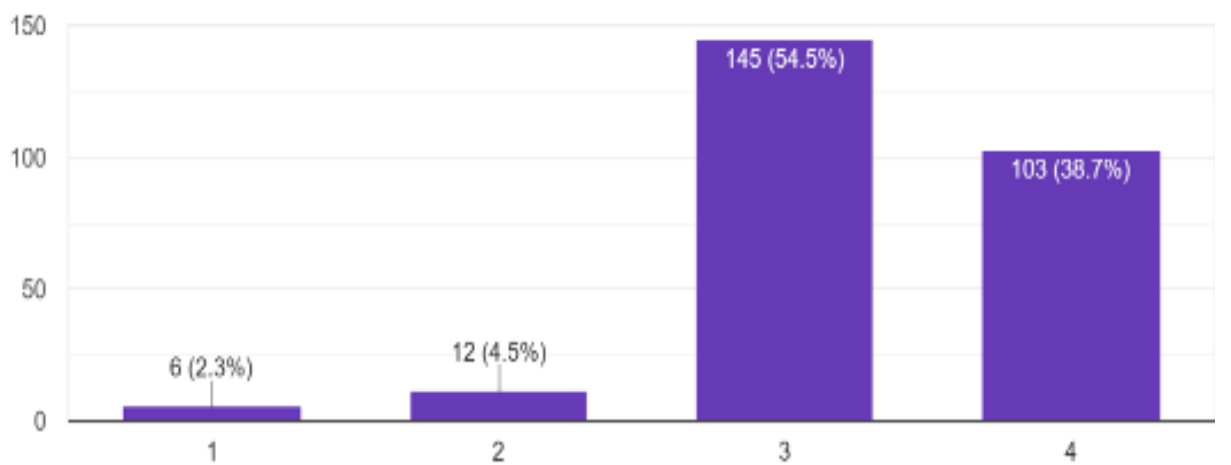

Gambar 21. Grafik Saya Tidak Akan Membeli Daging Sapi yang Tidak Aman dan Tidak Sehat

Dari data 266 responden mengenai perilaku hukum, penulis mengajukan 6 pertanyaan yaitu Saya menjaul sapi yang sehat dan aman, sebelum menjual/membeli sapi saya memastikan sapi yang dijual sehat dan aman, dalam membeli daging sapi saya mengecek terlebih dahulu kualitasnya, jika sapi saya sakit atau meninggal saya tidak akan menjualnya ke pemotongan hewan, saya tidak akan menjual daging sapi yang tidak aman dan sehat bagi konsumen hasilnya hampir $80 \%$ masyarakat setuju dan sangat setuju sementara $20 \%$ masyarakat ada yang setuju.

\section{PEMBAHASAN}

1. Perlindungan Hukum terhadap Peredaran Daging Sapi di Kabupaten Boyolali

Menurut Muchsin(2003), perlindungan hukum merupakan suatu hal yang melindungi subjek-subjek hukum melalui peraturan perundang-undangan yang berlaku dan dipaksakan pelaksanaannya dengan suatu sangsi, perlindungan hukum dapat dibedakan menjadi dua, yaitu:

\section{a. Perlindungan Hukum Preventif}

Penggunaan hukum hukum untuk dijadikan instrumen adalah perkembangan mutakhir dalam sejarah hukum untuk dapat sampai di tingkan perkembangan tersebut diperlukan persyaratan tertentu. Dalam peraturan menteri tersebut pada pokoknya terdapat 6 (enam) poin yang harus dipenuhi oleh pelaku usaha gara memberikan perlindungan yang baik kepada konsumen atau pembeli daging sapi, yaitu mengenai persyaratan rumah potong hewan, persyaratan unit penanganan daging, persyaratan higiene dan sanitasi, pengawasan kesehataan mayarakat veteriner, izin mndirikan rumah potong hewan dan izin usaha pemotongan hewan, sumber daya manusia, berikut pembahasan mengenai persyaratan rumah potong hewan yang pada dasarnya merupakan upaya pemerintah dalam hal memberikan perlindungan hukum secara preventif dan implikasinya di dalam masyarakat Indonesia yaitu sebagai berikut:

1) Persyaratan Rumah Potong Hewan

Persyaratan yang harus dipenuhi RPH agar tidak mengganggu masyarakat umum dan juga tidak menimbulkan pencemaran bagi lingkungan sekitar. Selain itu, persyaratan sarana pendukung dan persyaratan peralatan ini dimaksudkan agar daging yang diolah dan proses pengolahan atau pemotongan terjamin mutu dan kesehaatannya. Dengan demikian, berdasarkan data yang diperoleh persyaratan mengenai rumah potong hewan ini pada praktiknya tidak dilaksanakan dengan baik dan pengawasan dari pemerintah sangat minim. Penyebabnya berimbas pada masih berjalannya praktik peroduksi daging yang kurang sehat tanpa memperhatikan peralatan, sarana dan prasarana yang digunakan di dalam melakukan pengolahan daging. 
2) Persyaratan Unit Penanganan Daging

Dari data yang diperoleh, dengan demikian, mengakibatkan daging yang diterima oleh konsumen akan berpotensi tidak sehat dan aman apabila tidak dilakukan persyaratan dan perlakuan yang baik terhadap daging tersebut. Dengan masih beroprasinya rumah potong hewan yang tidak lengkap menunjukan apabila masih adanya kekurangan perlindungan hukum yang dilakukan oleh pemerintah terkait dengan konsumen yang membeli daging sapi.

\section{3) Persyaratan Higiene dan Sanitasi}

Dari data yang diperoleh, dengan demikian diperlukan pengawasan dan perlindungan hukum dilakukan oleh pemerintah dan dinas terkait untuk melakukan tindakan yang tegas mengenai persyaratan yang dipenuhi oleh rumah potong hewan ini agar daging yang beredar di dalam masyarakat merupakan daging yang sehat dan aman.

4) Pengawasan Kesehatan Masyarakat Veteriner

Ketentuan ini sangat penting katena akan berdampak secara langsung terhadap kesehatan manusia, perlu dilakukan penegakan ketentuan ini dengan baik dan perlindungan hukum dari pmerintah harus baik. Dari data yang diperoleh hal ini menunjukkan apabila pengawasan kesehatan veteriner masih sangat kurang dan perlu ditingkatkan lagi perlinudngan yang dilakukan agar daging yang beredar di masyarakat merupakan daging yang sehat dan aman.

5) Izin Mendirikan Rumah Potong Hewan dan Izin Usaha Pemotongan Hewan

Dari data yang diperoleh dengan demikian perlindungan hukum yang diberikan oleh pemerintah masih sangat minim, karena masih adanya pelaku usaha yang beroprasi tetapi tidak memiliki izin usaha.

\section{6) Sumber Daya Manusia}

Dari data yang diperoleh seluruhnya terdapat rumah potong hewan yang memiliki tenaga ahli di dalam pemotongan hewan, akan tetapi untuk dokter hewan tidak dimiliki. Dengan demikian, sumber daya manusia yang dimiliki sangat minim.

Terkait dengan data sebagaimana yang diuraikan di atas merupakan ketidaksesuaian antara ketentuan perundang-undangan dengan kenyataan yang ada di lapangan, sebagaimana yang disampaikan oleh Karl Renner yang menyatakan apabila "the development of the law works out what is socially reasonable" yang dimana pandangan itu bisa dipahami jika bertolak pada pandangan kompleksitas hukum, yaitu mengenai sektor formal dan non formal (yang muncul di dalam masyarakat) selalu berkaitan satu dengan yang lainnya, manakala hukum atau proses formal macet, maka kekuatan otonomi akan mengambil alih. Untuk mengatasi hal tersebut penulis ini penulis melakukan wawancara dengan Dina Sulistyowati selaku staf fermanim di Dinas Kesehatan Kabupaten Boyolali, penulis mengajukan pertanyaan yaitu:

1. "Apa saja yang menjadi kategori daging yang sehat dan aman untuk di konsumsi?" Jawab:

"Kategori daging sehat dan aman yaitu segar, tidak bau busuk, tidak mengandung bakteri, tidak tercampur atau terkontaminasi dengan bahan kimia yang tidak diijinkan untuk dikonsumsi oleh konsumen."

2. “Apa dampak kesehatan apabila mengkonsumsi daging sapi yang tidak sehat?" Jawab: 
a) Kalau tidak sehat akan menyebabkan diare karena mengandung banyak bakteri,

b) Keracunan."

3. “Apa saja peraturan Kesahatan yang mengatur mengenai peredaran daging sapi yang tidak aman dan sehat?"

Jawab:

a) Pengawasan daging pangan, tupoksi olahan pangan kering, UU Pangan, pengawasan olahan pangan PERKA BPOM No.22 TAHUN 2018 tentang cara produksi pemberian serttifikat produksi pangan yang baik bagi industri rumah tangga,

b) Pengawasanya PERKA NO 23 Tahun 2018.”

4. "Bagaimana langkah Dinas Kesahatan Boyolali untuk mencegah peredaran daging yang tidak aman dan sehat beredar di masyarakat?"

Jawab:

a. "Sosialisasi tentang cara pemilihan maupun pengolahan produk olahan daging pada masyarakat biasanya sasaran kami terutama di seksi farmanim adalah para pelaku usaha yang membuat olahan pangan daging dan sebagainya

b. Ada penyuluhan keamanan pangan, rutin melakuakan sasarannya ke produsen

c. Kegiatan dengan sasaran anak sekolah karena anak anak tidak luput dari makanan yang berasal dari olahan daging, sosialisasi di sekolah sekolah dengan waktunya menyesuaikan, terkait untuk mencegah supaya untuk mengurangi peredaran olahan daging yang tidak sehat, setahun 1 sampai 2 kali, tahun 2019 agak berkurang, ditahun sebelumnya ada

d. Uji pangan, kandungan pangan yang berbahaya yang beredar baik itu di pangan olahan rumah tangga maupun di sekolah-sekolah."

5. "Bagaimana menurut Saudara kesadaran hukum masyarakat di Boyolali terhadap kemanan daging sapi di Boyolali?"

Jawab:

"Kesadaran hukumnya Dinas Kesehatan masuk kedalam tim kesehatan hari raya, pemantauan pasar sebelum hari raya dengan berkerjasama dengan Dinas Ketahanan Pangan dan Dinas Pertenakan yang memang domainnya mereka, setahun dua kali, trendnya lebih baik, pemantauan dilakukan dengan pembinaan, walaupun tidak secara signifikan tapi adalah kesadaran penjual menjual daging yang sehat, tidak menjual daging yang tidak sehat."

6. "Apakah pernah terjadi kasus di Boyolali terkait kesehatan masyarakat karena mengkonsumsi daging sapi yang tidak aman dan sehat?"

Jawab:

"Belum menemui, kalau ada di tim keamanan Hari Raya ada tetapi belum dikonsumsi, kemudian dilakukan penindakan, belum sampai dikonsumsi."

7. Apakah menurut saudara penegakan hukum yang berjalan selama ini sudah mampu memberikan perlindungan kepada konsumen daging sapi?

Jawab;

"Penegakan hukum, tupoksi di pembinaan, sebatas yang di tahu belum ada kasus."

Terkait dengan upaya-upaya yang dilakukan untuk mencegah peredaran daging sapi yang tidak aman dan sehat terjadi dilakukan beberapa upaya yaitu sebagai berikut: 
a. Sosialisasi tentang cara pemilihan maupun pengolahan produk olahan daging pada masyarakat biasanya sasaran kami terutama di seksi farmanim adalah para pelaku usaha yang membuat olahan pangan daging dan sebagainya.

b. Ada penyuluhan keamanan pangan, rutin melakuakan sasarannya ke produsen

c. Kegiatan dg sasaran anak sekolah karena anak anak tidak luput dari makanan yang berasal dari olahan daging, Sosialisasi di sekolah sekolah dengan waktunya menyesuaikan, terkait untuk mencegah supaya untuk mengurangi peredaran olahan daging yang tidak sehat, setahun 1 sampai 2 kali, tahun 2019 agak berkurang, ditahun sebelumnya ada

d. Uji pangan, kandungan pangan yang berbahaya yang beredar, baik itu di pangan olahan rumah tangga maupun di sekolah-sekolah.

\section{b. Perlindungan Hukum Represif}

Perlindungan hukum represif merupakan perlindungan akhir berupa sanksi seperti denda, penjara, dan hukuman tambahan yang diberikan apabila sudah terjadi sengketa atau telah dilakukan suatu pelanggaran. Dalam hal ini penulis telah melakukan wawancara dengan beberapa pihak yang terkiat dengan perlindungan represif ini. Menurut Hendro, kasi kesehatan masyarakat feteriner terkiat dengan perlindungan secara represif selama ini belum ada, jika kasus berarti daging tersebut dikonsumsi oleh masyarakat dan harus menimbulkan dampak. Setelah itu, diuji secara laboratorium terbukti mengandung bahan yang berbahaya atau tidak, selama ini tidak ada laporan dampak seperti itu, missal ada harus dibuktikan dengan uji laboratorium, penyebab sakit tersebut karena mengkonsumsi daging sapi atau mengkonsumsi makanan yang lain. Labolatorium uji lab dan dari uji pasien tersebut secara teknis harus tepat tidak bisa berdasarkan prasangka. Ditelusuri daging sapinya, berasal dari mana apa betul karena daging sapinya atau proses selama distribusinya itu seperti itu bisa terjadi.

Hal ini dipertegas oleh Anang Mochdiono dan Yogi Pratama selaku penyidik pembantu \& Satgas Pangan Polres Boyolali, di mana penulis mengajukan pertanyaan sebagai berikut:

1. "Berapakah kasus yang pernah ditangani Polres Boyolali terkait dengan peredaran daging sapi yang tidak sehat dan aman?"

Jawab:

"Belum pernah ada kasus mengenai kasus peredaran daging yang tidak sehat dan aman di Kabupaten Boyolali selama ini."

2. "Tindakan apa yang sering ditemukan terkait dengan kasus peredaran daging sapi yang tidak sehat dan aman?"

Jawab:

"Tindakan yang dilakukan yaitu dengan berkoordinasi dengan Dinas Kesehatan untuk memastikan daging yang bersangkutan layak dikonsumsi atau tidak, jika dinas kesehatan mengatakan daging yang dijual tidak layak konsumsi baru Polres Boyolali akan menindak melalui proses hukum."

3. "Dikenakan jerat hukum apakah apabila masyarakat melakukan peredaran daging sapi yang tidak sehat? Peraturan hukum yang dikenakan?"

Jawab:

"Jerat hukum yang digunakan, perlindungan konsumen dan undang-undnag pangan, banyak celahnya, ancaman pidana mengikuti peraturan peundang-undangan yang digunakan."

4. "Apakah penegakan hukum yang dilakukan dalam menangani kasus peredaran daging sapi yang tidak sehat dan aman di Kabupaten Boyolali sudah berjalan dengan baik?" 
Jawab:

"Belum pernah ada kasus mengenai peredaran daging yang tidak sehat dan aman selama ini, jadi hal ini bisa dapat dikatakan penegakan hukum yang berhasil atau malah penegakan hukum yang gagal, berhasil karena tidak ada penegakan yang ditemukan dengan demikian masyarakat bagus, penegakan hukum gagal bila polisi atau dinas terkait yang tidak mengetahui atau memiliki informasi mengenai peredaran daging yang tidak sehat dan aman dilakukan."

5. "Bagaimana langkah yang dilakukan oleh Polres Boyolali untuk mencegah adanya peredaran daging sapi yang tidak sehat?"

Jawab

"Langkah yang dilakukan untuk melakukan pencegahan yaitu:

a. Melaksanakan himbauan kepada tempat-tempat pemotongan hewan agar melaksanakan pemotongan hewan sesuai dengan ketentuan, jika didapati tidak dilakukan sesuai dengan ketentuan, maka akan dilakukan penindakan.

b. Berkoordinasi dengan dinas terkait untuk melakukan sidak di pasar."

6. "Apakah yang menjadi kendala penegakan hukum peredaran daging sapi yang tidak aman dan tidak sehat di Kabupaten Boyolali?"

a. Faktor hukumnya?

Tidak ada kendala, sudah ada peraturan yang mengaturnya seperti undang-undang perlindungan konsumen dan undang-undang pangan

b. Faktor penegak hukum (jumlah personil)

Sudah mencukupi, di setiap kecamatan sudah ada kantor polisi, jadi personal sudah cukup

c. Faktor sarana atau fasilitas yang mendukung proses penegakan hukum (wilayah)

Mungkin adanya keterbatasan informasi terkait dengan adanya peredaran daging sapi yang tidak sehat dan aman karena dalam hal ini tindakannya sangat sulit untuk di buktikan, perlu ada dampak di masyarakat terlebih dahulu agar diketahui adanya peredaran daging sapi yang tidak sehat dan aman, ada dampak baru ada tindakan, keterbatasan infromasi, tidak memerlukan adanya pengaduan, khusus UU Perlindungan Konsumen, harus ada konsumen yang dirugikan.

d. Faktor masyarakat yaitu lingkungan dimana hukum tersebut berlaku atau diterapkan?

Kondusif tidak ada perlawanan, namun kesadaran masyarakat untuk melaporkan adanya tindak pidana masih kurang. Dengan demikian, informasi yang didapat tidak lengkap."

7. "Apakah solusi ke depan untuk melakukan penegakan hukum yang progresif terkait dengan kasus peredaran daging sapi di Kabupaten Boyolali?

Jawab:

Selalu berkoordinasi dengan dinas terkait, DISPERINDAG, Dinas Kesehatan dan dinas lainnya selain itu juga mengajak peran serta masyarakat untuk ikut serta melakukan penegakan hukum perdaran daging sapi yang tidak sehat dana aman."

Dari wawancara tersebut belum pernah ada kasus mengenai kasus peredaran daging yang tidak sehat dan aman di Kabupaten Boyolali selama ini. Jadi, hal ini bisa dapat dikatakan penegakan hukum yang berhasil atau malah penegakan hukum yang gagal, berhasil karena tidak ada penegekan yang ditemukan. Dengan demikian, masyarakat bagus, pengekan hukum gagal bila polisi atau dinas terkait yang tidak mengetahui atau memiliki infromasi mengenai peredaran daging yang tidak sehat dan aman dilakukan. Hal ini 
dikarenakan kurangnya kesadaran masyarakat yaitu terkait dengan akses informasi adanya keterbatasan informasi terkait dengan adanya peredaran daging sapi yang tidak sehat dan aman karena dalam hal ini tindakannya sangat sulit untuk di buktikan, perlu ada dampak di masyarakat terelebih dahulu agar diketahui adanya peredaran daging sapi yang tidak sehat dan aman, Ada dampak baru ada tindakan, keterbatasan infromasi, tidak memerlukan adanya pengaduan. Khusus UU Perlindungan Konsumen harus ada konsumen yang dirugikan sementara itu kesadaran masyarakat untuk melaporkan adanya tindak pidana masih kurang. Dengan demikian, infromasi yang didapat tidak lengkap.

Dari beberapa keterangan terhadap pihak terkait tersebut dapat diketahui apabila proses perlindungan hukum secara represif di Kabupaten Boyolali belum berjalan dengan baik. Hal ini jika dibandingkan dengan data yang diperoleh oleh penulis banyak pelanggaran ketentuan oleh pelaku usaha di Kabupaten Boyolali yang berpotensi terhadap beredarnya daging yang tidak sehat dan aman di Kabupaten Boyolali. Namun, selama ini tidak pernah ada pelanggaran yang ditemukan oleh Dinas Peternakan Kabupaten Boyolali atau Dinas Kesehatan Kabupaten Boyolali maupun Kepolisian Reserse Kabupaten Boyolali, mereka mengalami kendala apabila adanya keterbatasan informasi karena untuk adanya suautu penindakan diperlukan suatu dampak terlebih dahulu baru terdapat tindakan. Dengan demikian, diperlukan peran serta masyarakat dan kesadaran hukum masyarakat untuk memberikan informasi kepada masyarakat guna memberikan informasi kepada aparat penegak hukum agar perlindungan hukum secara represif ini dapat berjalan dengan baik.

\section{Konsep Perlindungan Hukum terhadap Peredaran Daging Sapi Berbasis Kesadaran Hukum Masyarakat}

Kesadaran hukum yang diteliti di sini adalah kesadaran hukum masyarakat terhadap peredaran daging sapi di Kabupaten Boyolali. Untuk memperoleh data, diambil sampel di Boyolali sebanyak 266 Responden yang mewakili kelurahan yang ada di masing masing kecamatan. Teknik pengumpulan data yang digunakan adalah penyebaran quisoner dengan media cetak dan kuesioner melalui google form. Indikator-indikator untuk mengukur kesadaran hukum masyarakat menurut Soerjono Soekanto adalah sebagai berikut:

\section{a. Pengetahuan hukum}

Dari data yang diperoleh penulis masih banyak masyarakat yang tidak mengetahui perlindungan hukum yang seharusnya mereka peroleh. Dengan demikian, perilaku mereka akan membiarkan sesuatu yang seharusnya tidak diperbolehkan karena ketidaktahuan hukum itu sendiri.

b. Pemahaman hukum

Dari data yang diperoleh penulis dan dikarenakan dengan pemahaman yang rendah menyebabkan masyarakat tidak mengetahui apakah daging yang ia konsumsi sehat dan aman atau tidak, selain itu kesadaran masyarakat dalam hal ini juga rendah. Hal ini berkesesuaian dengan data yang telah diuraikan sebelumnya apabila perlindungan hukum baik itu secara preventif dan represif belum berjalan sesuai dengan ketentuan perundangundangan. Dengan tidak adanya kasus atau laporan dari masyarakat mengenai hal ini menunjukkan apabila pemahaman hukum masyarakat masih rendah.

\section{c. Sikap hukum}

Dari data yang diperoleh dari masyaarakat tersebut, maka masyarakat memiiki sikap hukum yang baik meskipun masih ada beberapa masyarakat yang kurang baik terhadap penilaian mengenai hukum itu sendiri, masyarakat juga memhami mengenai penilaian mana tindakan baik dan tindakan yang tidak baik, yang ditunjukkan lebih dari $60 \%$ masyarakat memiliki sikap yang baik, sementara di beberapa aspek $40 \%$ masyarakat 
masih memiliki sikap hukum yang kurang baik. Dengan demikian, hal ini menunjukkan apabila tingkat kesadaran hukum akan memengaruhi tingkat perlindungan hukum yang baik, akan tetapi meskipun sikap hukum yang dilakukan baik tidak disertai dengan pengetahuan, pemahaman dan perilaku hukum akan menyebabkan tidak berjalannya sesuai dengan ketentuan perlindungan hukum itu sendiri.

\section{d. Perilaku hukum}

Menurut Hans Kelsen, hukum digambarkan sebagai domain steril (bebas nilai) terpisah dari etis dan moral, disadari atau tidak ilmu hukum hidup dan berkembang dari pola perilaku (pattern of behavior) di dalam masyarakat. Jadi, perilaku hukum merupakan seseorang yang mematuhi peraturan hukum yang berlaku, yaitu yang dimana dalam penelitian ini adalah kepatuhan masyarakat Kabupaten Boyolali dalam mematuhi ketentuan mengenai peredaran daging sapi di Kabupaten Boyolali.

Dengan demikian, hal itu menunjukkan perilaku hukum yang masyarakat terkait dengan pola pembelian sapi. Akan tetapi, masih juga ada beberapa orang yang memiliki perilaku hukum yang kurang baik. Namun, untuk satu pertanyaan terkait dengan jika mengetahui perilaku masyarakat yang melakukan penjualan sapi/daging sapi yang tidak aman dan sehat, saya melaporkan ke aparat penegak hukum hasilnya $30.8 \%$ masyarakat setuju, $7.5 \%$ masyarakat sangat setuju, sebanyak $41.7 \%$ tidak setuju, dan $19.9 \%$ masyarakat sangat tidak setuju. Hal ini menunjukkan dan akan berdampak kepada perlindungan hukum yang dilakukan secara preventif atau represif sikap acuh dan tak acuh dari masyarakat ini memengaruhi kesadaran hukum masyarakat. Apatisme masyarakat terhadap aparat penegak hukum juga menjadi faktor penentu, masyarakat tidak percaya dengan penegak hukum atau pemikiran negatif terhadap aparat penegak hukum. Oleh karena itu, untuk mengembalikan penegakan dan citra lembaga peradilan perlu melakukan perenungan yang lebih dalam memaknai kehidupan sosial dalam negara hukum.

Dengan demikian, dari uraian mengenai penegetahuan hukum, pemahaman hukum, sikap hukum dan pola perilaku hukum tersebut merupakan satu kesatuan yang tidak boleh terpisah, baiknya sikap hukum dan pola perilaku hukum jika tidak dibarengi dengan pengetahuan hukum dan pemahaman hukum yang baik tidak akan memberikan dampak kesadaran hukum yang baik pula. Dalam hal ini sebagaimana yang disampaikan oleh Hart yang menyatakan Hart percaya apabila manusia terbatas niat baik untuk orang lain meskipun secara moralitas manusia secara khusus memiliki tanggung jawab dan malu atas tindakan terburuk yang tidak bisa dihindari, yang dalam hal ini membuktikan keniscayaan tuhan sebagai sumber pertanggungban yang diberikan. Uraian Hart tersebut berkorelasi dengan data yang diperoleh penulis, yaitu pada dasarnya masyarakat memiliki sikap hukum dan perilaku hukum yang baik. Jadi, pada dasarnya kesadaran hukum ini memberikan pengaruh yang sangat besar terhadap tingkat perlindungan hukum karena aparat penegak hukum dalam hal ini tidak dapat memberikan upaya perlindungan hukum jika tidak disertai dari dukungan masyarakat. Oleh karena itu, tingkat perlindungan hukum sangat dipengaruhi oleh kesadaran hukum.

\section{SIMPULAN}

Berdasarkan hasil penelitian dan pembahasan dapat disimpulkan bahwa pertama, perlindungan hukum terkait dengan peredaran daging sehat dan aman di Kabupaten Boyolali belum berjalan dengan baik atau sesuai dengan ketentuan perundang-undangan. Hal itu dibuktikan dengan masih banyaknya pelanggaran mengenai ketentuan-ketentuan di dalam pengelolaan RPH yang dilakukan oleh pelaku usaha yang menyebabkan potensi peredaran daging sapi yang tidak sehat dan aman. Kedua, perlindungan hukum peredaran daging sapi berbasis kesadaran hukum, kesadaran hukum merupakan faktor pendukung perlindungan hukum yang dilakukan oleh masyarakat melalui faktor pengetahuan hukum, 
pemahaman hukum, meskipun didukung oleh faktor sikap hukum dan pola perilaku hukum yang baik.

Dalam hal ini penulis memberikan saran perlindungan hukum secara preventif dan represif peredaran daging sapi adalah upaya memberikan kualitas konsumsi masyarakat yang aman dan sehat namun kenyataannya belum berjalan baik disebakan salah satunya karena kesadaran hukum masyarakat yang kurang baik, dalam penelitian ini penulis mengharapkan, pertama, untuk pemerintah melalui dinas terkait atau aparat penegak hukum turut serta meningkatkan kesadaran hukum agar tingkat perlindungan hukum yang diberikan juga baik. Kedua, mengharapkan untuk masyarakat agar berperan lebih aktif di dalam perlindungan hukum terhadap peredaran daging sapi. Ketiga, mengharapkan untuk penelitian selanjutnya agar menggunakan dan memanfaatkan penelitian ini sebagai salah satu referensi dan penelitian yang akan dilakukan.

\section{DAFTAR PUSTAKA}

. (2011). Kapita Selekta Ilmu Hukum. Yogyakarta: Liberty.

(2017). Morality and law: Critics upon H.L.A Hart's Moral Paradigm Epistemology Basis based on Prophetic Paradigm. Jurnal Dinamika Hukum, 17(1), 24-30. http://doi.org/10.20884/1.jdh.2017.17.1.823.

Absori dan Achmadi. (2017). Transplantasi Nilai Moral dalam Budaya untuk Menuju Hukum Berkeadilan (Perspektif Hukum Sistematik ke Nonsistematik Charles Sampord). Prosiding Konferensi Nasional ke 6, Asosiasi Program Pascasarjana Perguruan Tinggi Muhammadiyah Aisyiyah (APPPTMA).

Absori dan Syiblunnur, M. (2017). Perlndungan Hukum Pada Pelayanan Kesehatan Tingkat Pertama di Kabupayen Kotawaringin Timur, Surakarta: Megister Ilmu Hukum Universitas Muhammadiyah Surakarta.

Absori, Dimyati, K., \& Wardiono, K. (2008). Model Penyelesaian Sengketa Lingkungan Melalui Lembaga Alternatif. Mimbar Hukum, 2 (2), 193-410. http://doi.org/10.22146/jmh.16308.

Absori, Samsuri, T, \& Dimyati, K. (2018). Justice-Based Health Law: Study of Profession Equality Based Justice on Social Justice. Jurnal Dinamika Hukum, 18 (2), 163-171. http://doi.org/10.20884/1.jdh.2018.18.2.1082.

Absori. (2005). Penegakan Hukum Lingkungan pada Era Reformasi. Jurnal Ilmu Hukum, $8(2), 221-237$.

Agung. (2016, Juni 30). “Mewaspadai Makanan Tak Halal Menjelang Idul Fitri”., diakses tanggal 7 Januari 2019, dari ugm.ac.id/id/berita/12032-mewaspadai.makanan.tak.halal.menjelang.idul.fitri

Ali, A. (2012). Meeguak Teori Hukum (legal Theory) dan Teori Peradilan (Judicialprudence) termasuk interpretasi Undang-undang (Legisprudence). Jakarta: Kencana.

Aryogi dan Romjali, E. (2017). Potensi, Pemanfaatan dan Kendala Pengembangan Sapi Potong Lokal Sebagai Kekayaan Plasma Nutfah Indonesia. Pasuruan: Lokakarya Nasioanl Pengelolaan dan Perlindungan Sumber Daya Genetik di Indonesia: Manfaat Ekonomi untuk Mewujudkan Ketahanan Nasional.

Indiraningsih, S. (2013). Identifikasi Penyebab Kematian Sapi Potong dalam Program PSDS-K di Jawa Tengah. Seminar Nasional Teknologi Peternakan dan Veteriner.

Marzuki, L. (1995). Siri Bagian Kesadaran Hukum Rakyat Bugis Makasar. Makasar: Hasanuddin Univeristy pers.

Mertokusumo, S. (1981). Meningkatkan Kesadaran Hukum Masyarakat. Yogyakarta: Liberty.

Muchsin. (2003). Perlindungan dan Kepastian Hukum bagi Investor di Indonesia, Surakarta: Magister Ilmu Hukum Program Pascasarjana Universitas Sebelas Maret.

Populasi sapi potong menurut provinsi 2009-2017. (2017, Januari 07). Badan Pusat Statistik Nasional, diakses pada hari senin 14 Januari 2019 dari 
https://www.bps.go.id/dynamictable/2015/12/18/1038/produksi-daging-sapimenurut-provinsi-2009-2017.html.

Soekanto, S. (1982). Kesadaran Hukum dan Kepatuhan Hukum. Jakarta: Rajawali Pers.

Subdirektorat Statistik peternakan .(2019). Direktori Perusahaan Pertanian Rumah Potong Hewan (RPH) dan Tempat Pemotongan Hewan (TPH) 2017, Jakarta: Badan Pusat Statistik. 